\title{
Concursos de Jardins no incremento do paisagismo ${ }^{(1)}$
}

\author{
VALCIR JAIME RAMPINELLI(2)
}

O homem quando fixou residência, deixou para trás o nomadismo percebeu que precisava melhorar ao seu redor. Relação essa intima e antiga, valendo de uma harmonia que sobrevive até os dias de hoje e certamente terá espaço por longos séculos. O jardim sempre fez parte da humanidade. A bíblia descreve o jardim de Éden.

A maioria da população já se encontra nas grandes cidades, formando verdadeiros amontoados, deixando o campo para uma minoria privilegiada que se estabelece nesse paraíso interiorano. Segundo Instituto Brasileiro de Geografia e Estatísticas (IBGE - 2011) em 1940 a população urbana era $31 \%$, contra $69 \%$ da população rural, enquanto que no ano de 2010 os números são assustadores, onde a população urbana chega a $84 \%$. Esse povo que colaborou com incremento populacional urbano, recorda e se angustia quando falta a harmonia das plantas ao seu redor. Esse desequilíbrio pode levar ao estresse, desconfortos e muita solidão. Parcela dessa população que deixou suas terras de grandes extensões por vezes busca no espaço urbano formar uma pequena lavoura, agora com plantas que ornamentam.

A pergunta que sempre nos forneceu interrogações e alguns porquês nos direcionavam pelo baixo consumo do paisagismo especialmente no nossa cidade, Criciúma situada ao sul de Santa Catarina. Essa indagação nos remeteu a elaborar a Monografia em 2007 através do curso de pós-graduação Lato Sensu em Plantas Ornamentais e Paisagismo da Universidade Federal de Lavras (MGBrasil). Sabíamos que os municípios de Forquilhinha e Treviso, ambos próximos da cidade de Criciúma, haviam elaborado concursos de jardins. A cidade de Forquilhinha em três edições $(1994,1995,1996)$ e Treviso em apenas uma edição em 2006. Buscávamos respostas desses trabalhos e suas consequências nas comunidades e também na região Sul de Santa Catarina.

A metodologia utilizada na elaboração da Monografia foi baseada em pontos fundamentais como, revisão bibliográfica sobre a história da relação do homem com o jardim e pesquisa de campo com os envolvidos nos concursos das comunidades citadas. A pergunta era inevitável, quais as contribuições que os concursos de jardins apresentaram para o paisagismo. Percebíamos ao longo das entrevistas juntamente com estudos bibliográficos que os resultados remetiam a evolução dessa arte em nossa região. As pessoas envolvidas relatavam com entusiasmo suas participações na formação dos seus jardins. Relata Dirce G. P. da Luz da comunidade de Santa Terezinha - Forquilhinha (2006). "Durante o concurso minha comunidade virou um jardim". Todos os relatos foram unânimes, em direção a essa atividade. Segundo Maristela Scarabelot, Extensionista Rural da cidade de Forquilhinha, membro da organização dos concursos nas três edições (2007). "Queríamos melhorar os arredores das propriedades e recuperação do saneamento ambiental, por isso iniciamos pelo jardim."

"O método escolhido foi o concurso, pois sabíamos que as comunidades atenderiam a essa provocação". Já o Engenheiro Agrônomo do município de Treviso, organizador do concurso relatou em 2007 que gostaria de criar o hábito pelo paisagismo potencializando o turismo utilizando essa metodologia. $\mathrm{O}$ que se percebe em ambos os casos era à vontade em obter a evolução do paisagismo, pois o diagnóstico não era favorável apesar da comunidade de Treviso estar em outra situação um pouco privilegiada em decorrência dos frutos colhidos no município de Forquilhinha.

A palavra concurso, do latim concursus significa ação de correr juntos. Porém a palavra sofreu desgastes na medida em que encontrou o capitalismo, o qual impôs a escolha dos melhores aproveitando-se dessa condição. Instaura a concorrência sem levar em consideração as heranças de diferentes aspectos. Então é inevitável a presença das mazelas como a inveja entre os competidores, em especial nas colonizações italianas e alemãs, ambas as sociedades também de fácil aceitação nesse tipo de proposta. Relata a professora Marlene Rosso da comunidade de Treviso "Tem que ter competição, caso contrário não há empenho". Segundo Joseph Epstein em seu livro Inveja (2004). "Errar talvez seja humano, mas invejar sem duvida é". Dessa forma compreendemos o aparecimento desse entrave, acrescentando os preconceitos contra o paisagismo com mais nitidez na colonização italiana que posteriormente foram superados por objetivos bem claros como mostra o quadro abaixo:

\footnotetext{
(1) Recebido em 10 de maio de 2013 e aceito para publicação em 30 junho de 2013.

(2) Engenheiro Agrônomo especialista em Plantas Ornamentais e Paisagismo jaimerampi@hotmail.com
} 


\begin{tabular}{|c|c|c|}
\hline Atividades/ Municípios & Forquilhinha SC & Treviso SC \\
\hline Projeto & Embelezamento de Forquilhinha & Treviso Bei fiori de Treviso \\
\hline Edições & 1994, 1995, 1996. & 2006. \\
\hline Objetivos & $\begin{array}{l}\text { Melhorar as condições de saneamento das } \\
\text { comunidades rurais, motivar para a coleta } \\
\text { seletiva do lixo, melhorar a qualidade da água. }\end{array}$ & $\begin{array}{l}\text { Criar o hábito do paisagismo, } \\
\text { potencializando o turismo. }\end{array}$ \\
\hline Organização & Prefeitura e EPAGRI. & Prefeitura e EPAGRI. \\
\hline Colaboradores & $\begin{array}{l}\text { Escolas, comunidades, Comerciantes, Clube de } \\
\text { mães. }\end{array}$ & Escolas e comunidades. \\
\hline Ações e critérios & Bem definidos. & Bem definidos. \\
\hline Categorias & Jardins rurais. & $\begin{array}{l}\text { Jardins urbanos e rurais } \\
\text { Jardins particulares e } \\
\text { comunitários }\end{array}$ \\
\hline Subsídios & Prefeitura municipal. & Prefeitura municipal. \\
\hline Premiação & $\begin{array}{c}\text { Ferramentas de jardinagem e viagem à cidade de } \\
\text { Gramado RS. }\end{array}$ & $\begin{array}{l}\text { Ferramentas de jardinagem e } \\
\text { certificado de participação. }\end{array}$ \\
\hline Outros & $\begin{array}{l}\text { Cursos intensivos nas comunidades } \\
\text { Visitação a jardins } \\
\text { Excursão com os envolvidos. }\end{array}$ & $\begin{array}{l}\text { Eleição para escolher a árvore } \\
\text { símbolo Ipê amarela (Tabebuia } \\
\text { chrysotricha) } e \text { Identificação das } \\
\text { árvores na praça central. }\end{array}$ \\
\hline
\end{tabular}

Fonte: EPAGRI - Empresa de Pesquisa Agropecuária e Extensão Rural de Santa Catarina - 2007 de Treviso e Forquilhinha.

Os concursos de jardins em especial as edições de Forquilhinha SC foram os grandes embriões na evolução do paisagismo na Região Sul de Santa Catarina, apesar de estarmos distante da nossa pretensão. A partir desse momento a direção do paisagismo tomou um rumo crescente influenciando a cidade de Treviso SC, e Região. Maristela Scarabelot, agora mestra em desenvolvimento rural descreveu em março de 2013. "A partir dos concursos de jardins pode-se observar um movimento crescente nos municípios vizinhos no tocante à melhoria de espaços públicos e propriedades rurais.
Hoje sentimos que o paisagismo é percebido como fator importante para a maioria dos gestores públicos, em especial para aqueles de desenvolvem processos alinhados ao turismo. Entendemos que os concursos de jardins e sua relação com as plantas, terra, água, gente, despertaram sentimentos associados ao cuidado com a vida."

O concurso de jardins é uma atividade que associada a outros projetos e ou trabalhos nas condições já discutidas com estudo detalhado das sociedades envolvidas permitem o incremento no paisagismo. 